\title{
The Cross-Channel Diffusion of the French May
}

La diffusion de mai 1968 outre-Manche

\section{Claire Mansour}

\section{(2) OpenEdition \\ Journals}

Electronic version

URL: https://journals.openedition.org/rfcb/8859

ISSN: 2429-4373

Publisher

CRECIB - Centre de recherche et d'études en civilisation britannique

Electronic reference

Claire Mansour, "The Cross-Channel Diffusion of the French May", Revue Française de Civilisation

Britannique [Online], XXVII-1 | 2022, Online since 04 January 2022, connection on 01 February 2022

URL: http://journals.openedition.org/rfcb/8859

This text was automatically generated on 1 February 2022.

\section{(c) (i) (9)}

Revue française de civilisation britannique est mis à disposition selon les termes de la licence Creative Commons Attribution - Pas d'Utilisation Commerciale - Pas de Modification 4.0 International. 


\section{The Cross-Channel Diffusion of the French May}

La diffusion de mai 1968 outre-Manche

Claire Mansour

\section{Introduction}

1 In May 1968, British historian Eric Hobsbawm wrote about the events of the French May: "What France proves is that when someone demonstrates that people are not powerless, they may begin to act again." ${ }^{1}$ Paris was proclaimed "City of Hope" by the radical left-wing newspaper Black Dwarf edited by Tariq Ali, ${ }^{2}$ and activists hoped that the shockwave of the French May would cause more than a few ripples across the Channel. But historians have for the most part concluded that there was no equivalent of the events of May 1968 in Britain. If activism did noticeably step up in the following months, it was by no means comparable in terms of size and intensity. Hence Arthur Marwick euphemistically refers to Britain's relative tranquillity as "echoes from the storm," ${ }^{3}$ while Dominic Sandbrook describes "the contrast between the parochial, small-scale events in Britain and the genuine upheaval and bloodshed in, say, France and the United States." ${ }^{\prime 4}$ Even though the French May did not generate an replica, it does not necessarily follow that it did not wield any influence on British protesters. Therefore, the aim of this article will be to assess the impact of the events of May 1968 on social protest in the United Kingdom, both in the short and long terms, mainly through the analysis of primary sources coming from the alternative press, and scholarly secondary sources.

2 The sociological concept of diffusion will be used to explain how information was transferred across the Channel. When applied to social movements, diffusion can be defined as the adoption of a set of elements by a group of protesters, the adopters, inspired by the original actions of a first group of activists, the transmitters. The diffused items are mediated through a combination of non-relational channels, like the media, or relational channels when direct personal contact is established between both groups. ${ }^{5}$ They can be of various sorts: abstract ideological elements, slogans, 
terminology, or of a more concrete nature like protest tactics. This article will seek to demonstrate that diffusion processes were at work between France and Britain in the wake of May 1968 and that they significantly influenced the course of events across the Channel.

\section{Channels of Diffusion}

\section{Perceived similarities between French and British activists}

3 According to sociologists Doug McAdam and Dieter Rucht, the perception of similarities between adopters and transmitters is a necessary condition for cross-national diffusion. ${ }^{6}$ This will in turn trigger a process of identification of adopters with transmitters which will act as a bond enabling the transfer between both groups.

After the Second World War, France and Britain experienced similar trends. Both countries entered periods of economic recovery and relative affluence, with a general improvement of living standards. They adopted policies of expansion of higher education, which caused overcrowding in universities - albeit to a different extent since France had to deal with twice as many university students as Britain. ${ }^{7}$ Nevertheless, British students were still complaining about cramped conditions in lecture halls and classrooms, as an editorial from the newspaper of the London School of Economics (LSE) indicates: "L.S.E. is bursting at its seams. The increased input of students seems to have resulted in an even greater output of overcrowding and confusion." similar criticisms were voiced by the students from provincial universities, like the University of Warwick. ${ }^{9}$ French and British students also shared a number of other grievances in the 1960s, such as low-student faculty ratio or infantilising campus rules like curfews in halls of residence or restricted visiting hours for guests. But above all, the cause of frustration among students sprang from their lack of participation in the running of their universities. They were not represented in most decision-making bodies and therefore had no say in disciplinary procedures, teaching matters and university life in general. On both sides of the Channel, the intellectual current of the New Left agitated for participatory democracy. The name New Left had been translated from the French "Nouvelle Gauche", and its followers sought to create an alternative to Soviet Communism and Social Democracy. ${ }^{10}$ It provided the ideological background of instrumental movements in the early 1960s which would pave the way for the protests at the end of the decade: the opposition to the Algerian War in France and the Campaign for Nuclear Disarmament in Britain, followed in both countries by opposition to the Vietnam War. These movements provided many participants with a first experience of collective action and stirred up political consciousness.

Likewise, workers also complained about their lack of control over the decisions that directly concerned them in their workplaces, such as working conditions, working hours, the manning of the machines or work organisation. With inflation on the rise and wages not keeping up with the cost of living, discontent was growing among workers. In Britain, wildcat strikes had been spreading since the 1950s, ${ }^{11}$ while the months of May and June 1968 saw the largest unofficial strike in French history, involving an unprecedented number of workers (estimates vary from five to ten million according to official sources and protesters respectively). ${ }^{12}$ Those perceived similarities 
with their French counterparts would lead British activists to identify with them, and adopt various items mediated through relational and non-relational channels.

\section{Non-relational channels of diffusion}

Diffusion mainly occurs through non-relational channels, both traditional forms of mass media like television, radio and newspapers but also the alternative press. In this particular instance, British radical left, underground and student publications played a crucial part in the transfer of ideology, slogans and tactics. Their editorial boards translated and published countless pamphlets, leaflets or cartoons used by French activists. As an example, The Black Dwarf printed in its June issue a translation of a leaflet issued by the Nanterre 22 March Movement voicing the students' grievances and calling for a demonstration on 10 May 1968 in Paris. ${ }^{13}$ Given that the action had already taken place when the leaflet appeared in the columns of the British newspaper, the aim of the editors could not have been to convince its readers to go protesting in Paris. They hoped to have them identify with Parisian students and resort to the same solution: collective action. Cartoons, posters and slogans were similarly borrowed, often accompanied by explanations reinforcing the parallels between the situations in both countries. The following piece, drawn by political cartoonist Siné and first published in the French student newspaper Action in May $1968,{ }^{14}$ shows a policeman teaching his colleagues how to beat up students by targeting vulnerable body parts as shown on the diagram behind him. It appeared the following month in The Black Dwarf with a translation of the caption "We're students too!". ${ }^{15}$

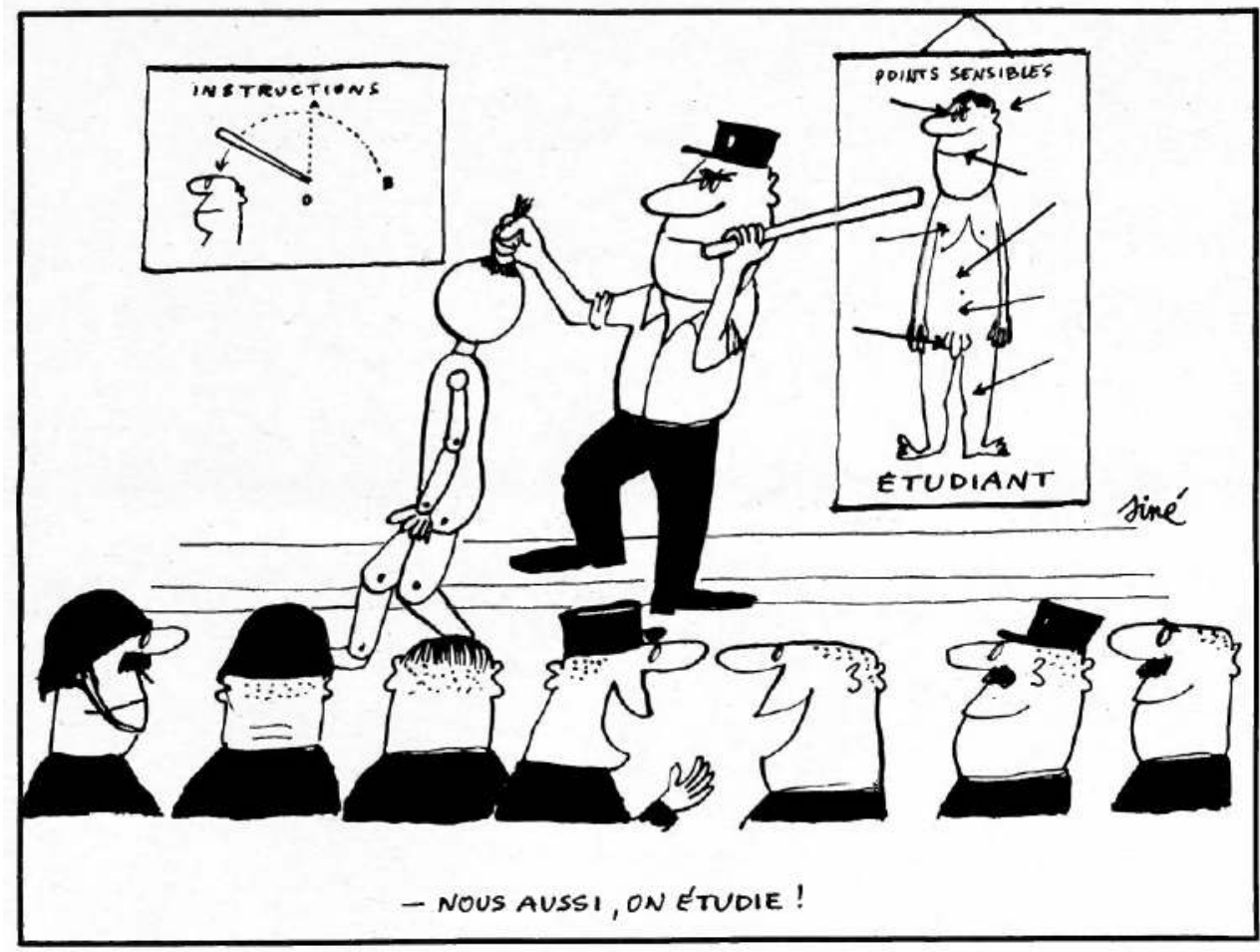




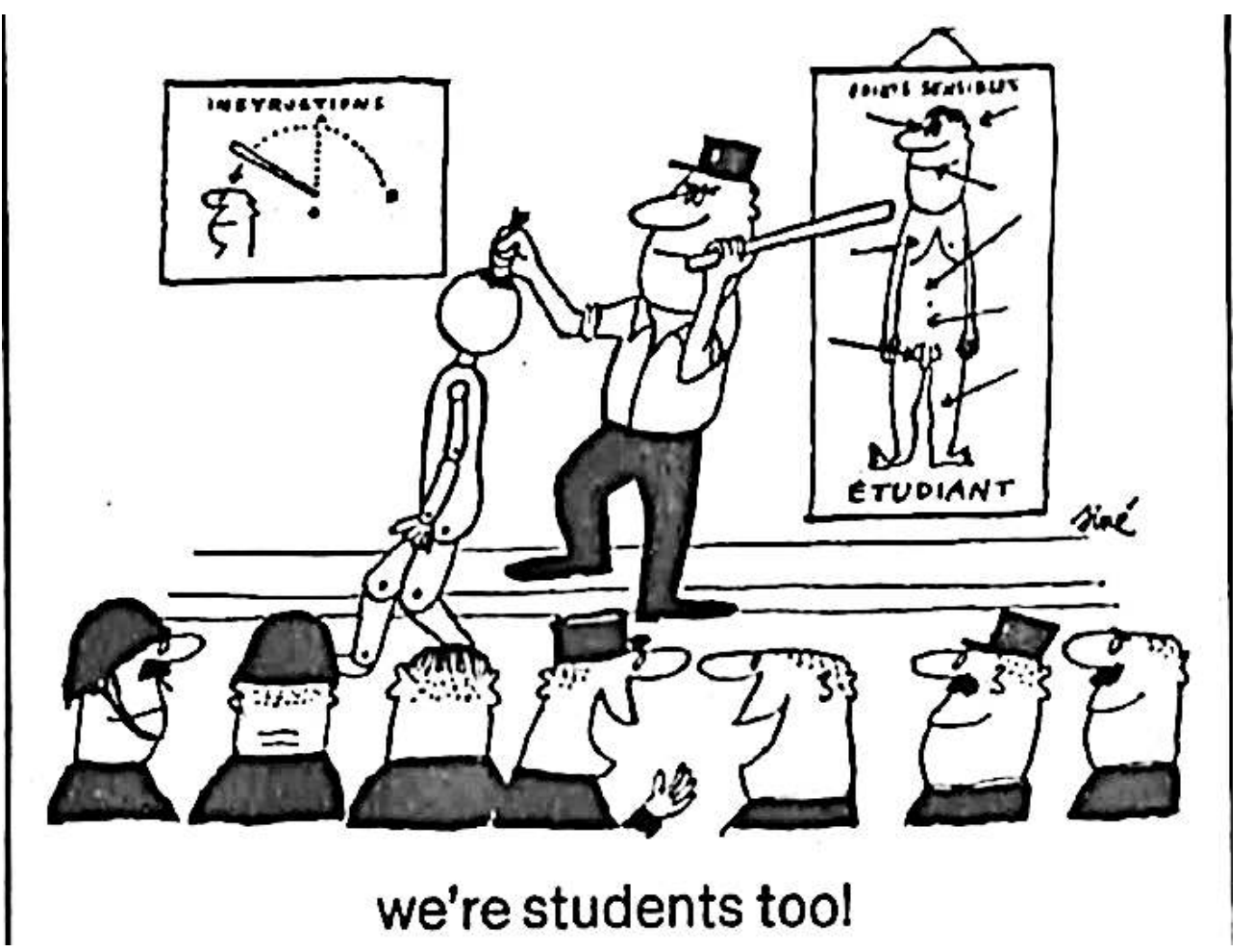

MEANWITA - IN FRANCE AND IN BRITAIN

THE STRUGGIE COMPINUES !

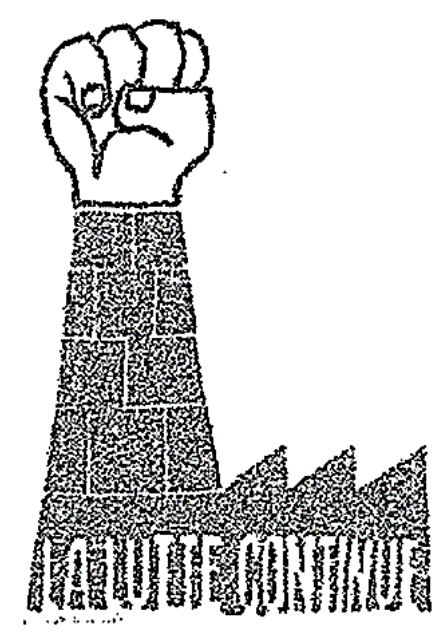

7 The picture above was published in another British radical left paper called Workers' Fight. ${ }^{16}$ It shows the French symbol of worker protests with a raised fist on the top of a factory chimney. Not only has the original slogan "la lutte continue" been translated, but the fight of the French and British workers was presented as one and the same "In France and in Britain, the struggle continues!". 


\section{Relational channels of diffusion}

Direct contact was also established between the transmitters and the adopters, hereby facilitating diffusion. Numerous British students and activists were in France in May 1968 and their first-hand accounts and testimonies were subsequently published in various alternative newspapers. For instance, the chronicles appearing in The Black Dwarf and Solidarity were so detailed that they covered the Night of the Barricades when student protesters erected barricades in the Latin Quarter on 10 May to protect themselves from police assaults - along with university and factory occupations almost hour by hour. ${ }^{17}$ The student leaders of the French May were also invited to London in June 1968. Both Alain Geismar and Daniel Cohn-Bendit spoke at the London School of Economics, at the founding conference of the Revolutionary Socialist Student Federation. This new organisation was created to give the student movement in Britain a more radical turn, in order to follow in the footsteps of their Parisian counterparts. ${ }^{18}$ Thanks to those personal links between both groups, the adopters were encouraged to borrow a selection of elements from the transmitters, among which collective action frames would play a crucial part in shaping their political outlook on their own situation.

\section{The diffusion of collective action frames}

American sociologists Robert Benford and David Snow define collective action frames as follows: "collective action frames are action-oriented sets of beliefs and meanings that inspire and legitimate the activities and campaigns of a social movement organization." ${ }^{19}$ In other words, they correspond to the way protesters perceive reality and interpret their situation in order to improve their conditions through collective action. Those frames are ideological elements which can be transferred from one social movement to another through diffusion processes. In the case of the French May, the similarities perceived by British protesters with activists across the Channel convinced them to adopt their collective action frames.

\section{Diagnostic frames}

10 Diagnostic frames refer to the way activists identify a set of problems in their current situation. ${ }^{20}$ British activists chose to use the diagnostic frames of the French May because they felt those frames resonated with their own situation, emanating from the perception of similar problems. Students and workers thought that they lacked control over their institutions, and that universities and factories were run solely according to the interests of the elite, at the expense of their own. In October 1968, a student expressed his views on the problems confronting his kind in the newspaper of the University of Warwick:

They [the students] must be moulded to the needs of the system, made to conform to curricula, designed not in the interests of learning or culture, but in the interests of profit-mongers in the City of London. This is why this university is run not by students (for whom it theoretically exists), not by the academic staff (whose livelihood it represents) but by a professional bureaucracy, responsible only to the capitalist state and the local industrialists who hold the purse strings and totally 
out of sympathy with any demands students or staff may make in their own material or cultural interests. ${ }^{21}$

11 According to this interpretation of the situation, the purpose of universities was not to guarantee the students' access to knowledge and intellectual emancipation, but to turn them into a skilled workforce serving the needs of the market. This Marxist frame of analysis was hardly new in Britain, capitalism having long been accused of being the underlying cause of social problems. But such views had been mainly restricted to radical left circles. At the time, the two most active organisations were International Socialists, created in the 1950 s by Tony Cliff under the name Socialist Review Group and then rechristened in 1962, and the International Marxist Group founded in 1966 by Pat Jordan and Ken Coates. The main ideological difference between both groups was that the latter saw students as a revolutionary vanguard who would play a key role in the fight for Socialism, while the former believed that only the working class could bring about a revolution..$^{22}$ In the wake of the French May, the Marxist diagnostic frame took centre stage and found its way into relatively moderate student newspapers from provincial universities, like those of the University of Warwick or the University of Leeds. ${ }^{23}$ In an article entitled "We are the nation's investment but are we being educated or exploited?" a Leeds student similarly pondered over the question, quoting Karl Marx to support his reasoning. ${ }^{24}$

However, in the eyes of the British activists, the main accomplishment of the French May resided in the worker-student alliance, which almost toppled de Gaulle's regime. This alliance had been made possible by the perception of both groups that they faced the same opponent: "la bourgeoisie" ("the bourgeoisie"), rebranded as "l'ennemi" ("the enemy"), to stress the convergence of both struggles. ${ }^{25}$ In the following weeks and months, the term "bourgeois" spread like wildfire in the student and radical left press: "bourgeois society", "bourgeois university", "bourgeois state" "bourgeois ideology", etc., were used to denounce the stranglehold of the capitalist elite on the political, educational and economic systems. ${ }^{26}$ British activists also used the motif of the common enemy confronting workers and students, fighting against "the same bosses" 27 and subjected to the same forms of state repression ("the obvious similarity of tactics employed against protesting students and 'unofficial' strikers"). ${ }^{28}$

\section{Frame bridging}

To facilitate the alliance between workers and students, their respective frames had to be aligned, through a process known as frame bridging. ${ }^{29}$ In both France and Britain, students were seen by some workers as a privileged minority, enjoying an easy life thanks to the taxpayers' money. In 1970-1971, about $8 \%$ of British school leavers went into higher education. There were 236,000 students attending universities and 204,000 in polytechnics. ${ }^{30}$ In order to bridge the gap separating them from the workers, students were presented as part of the working class. They drew attention to the fact that a rising proportion within their ranks came from working-class families, ${ }^{31}$ and started presenting themselves as the "the workers of the future" who would soon become "a skilled section of the working class". ${ }^{32}$ Activists also denounced the divide and rule strategy of the authorities, trying to set the workers against the students by emphasising class divisions. ${ }^{33}$ To some extent, the French May also contributed to dispel the stereotype of students as strike-breakers, which originated in the 1926 general strike, when many middle-class and upper-class students had enrolled to keep 
trains and buses running. ${ }^{34}$ This process of frame alignment was aimed at creating a sense of unity and common purpose to enable workers and students to join forces.

\section{Prognostic frames}

14 Prognostic frames are the solutions proposed to right the wrongs that have been identified in the diagnosis frames. ${ }^{35}$ Because British activists had identified the same problems as their French counterparts, they also favoured the same course of action to remedy them. In the short term, their aim was to empower workers and students, to allow them to participate directly and actively in the running of their universities and factories. In the long term, they hoped to establish a more democratic and egalitarian society. To these ends they chose direct action tactics which enabled them to put those ideals into practice: taking control of universities, factories, and even in some cases whole areas of towns and cities.

Hundreds of thousands of people of all ages have discussed every aspect of life in packed-out, non-stop meetings in every available schoolroom and lecture hall. [...] They proclaimed that democratic self-management was possible - and to prove it began to practice it themselves. [...] The tumultuous development of the students' struggle triggered off the first factory occupations. It transformed both the relation of forces in society and the image, in people's minds, of established institutions and of established leaders. ${ }^{36}$

This enthusiastic British eyewitness account of the Paris events clearly shows that one of the most inspiring aspects of the French May was the experiment in direct democracy. Because they wanted to achieve the same results, British protesters not only adopted collective action frames but also some of the tactics used by their models.

\section{The Diffusion of Tactics}

\section{University and factory occupations}

Within the framework of the worker-student alliance, French activists drew a parallel between university and factory occupations, both seen as means to give some control to workers and students over their own lives. "Nous occupons les universités, vous occupez les usines" ("We are occupying universities, you are occupying factories") a student declared in the French newspaper Action..$^{37}$ The same analogy was borrowed by their British counterparts in order to urge workers and students to follow in their footsteps. "Workers and students / Don't demand / Occupy / Your schools, your factories" enjoined the frontpage of The Black Dwarf in red and black block letters in October $1968 .{ }^{38}$ 
IThe Black Dwanf

"They say that in Mexico we have the most cultured army of all Latin America because it is continually in the universitics"..... Page 5

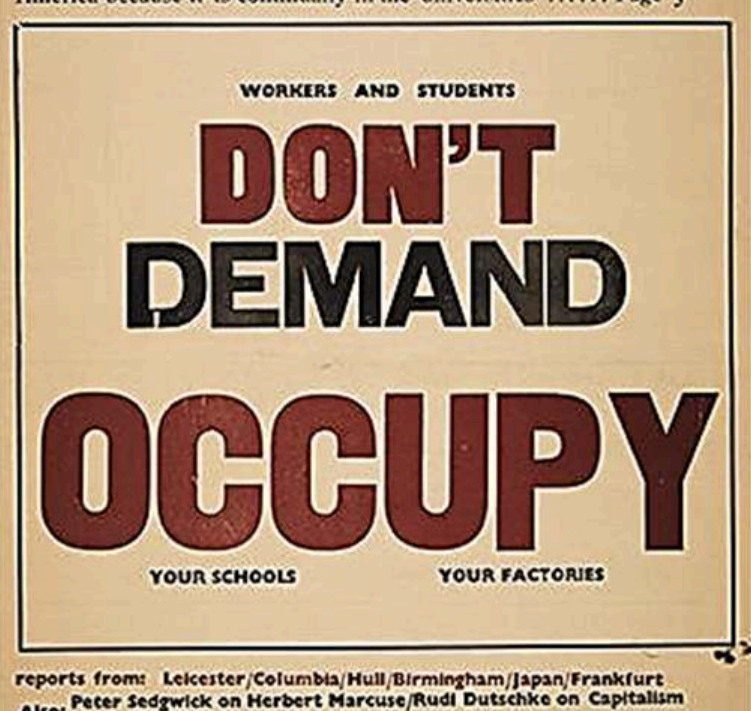
Alpecer sedzwick on Herbert Marcuse/Rudi Dutsehke on Capitalism Alsot, Pecer sedgwick on Heroter

\section{ALL POWER TO THE GAMPUS SOVIETS!}

Neither university nor factory occupations were innovations in Britain in 1968. The London School of Economics had been occupied for nine days in March 1967, ${ }^{39}$ so were Aston and Leicester universities, albeit very briefly, in the early months of $1968 . .^{40}$ But in the wake of the French May, the tactic certainly gained momentum. Students quickly seized control of the LSE again, the Hornsey College of Arts and the universities of Essex, Hull and Leeds. Before the year ended, the LSE had been occupied again, along with the universities of Birmingham and Bristol. ${ }^{41}$ The role of the French May as a source of inspiration can be seen in the various references made by the students. In Leeds, the radical group leading the occupation called itself the "May the $3^{\text {rd }}$ Committee" as a tribute to the Parisian students who had taken possession of the Sorbonne and were forcibly removed by the police on 3 May 1968, causing an upsurge in protest. ${ }^{42}$

Contrary to France, where the student movement dwindled after the climax of 1968, in Britain, it reached a peak in the early 1970s. Occupations became the lead tactic, with the most sustained wave occurring in 1970, sparked by the scandal of the Warwick Files. While they had been holding a sit-in in the administrative building of their university, the Warwick students discovered evidence of political spying on students and staff. The administration had been keeping confidential files with a detailed record of their political activities. The scandal quickly gained national prominence and the protests snowballed when other universities refused to open their files. Groups of activists broke into offices and occupied universities across the country, most notably in Glasgow, Hull, Edinburgh, Stirling, Birmingham, Essex, Manchester and Oxford. ${ }^{43}$

As for British workers, the uprising in France inspired a few attempts to occupy factories in the short term, but they ultimately failed due to lack of support. In Merseyside, for example, the workers of three factories belonging to the General Electric Company and English Electric formed an Action Committee in August 1969 in order to organise an occupation of their plants to protest against a mass redundancy plan. In their appeal to their colleagues, they justified their choice of tactics: "Our 
decision is to occupy and run our factories. This we believe has never before been attempted on such a scale by British workers." ${ }^{44}$ The precedents mentioned as a source of inspiration were "the factories in France last year" and in Britain that of "the militant students in the Universities last year." ${ }^{45}$ The tactic of factory occupation had therefore been the outcome of diffusion processes, but its proponents lost the vote and it was not carried out. By the early 1970s, the mood had grown more militant among workers, especially after the symbolic threshold of one million unemployed had been broken through in January 1972. That year, there was an unprecedented wave of factory occupations to fight against redundancy plans. In the area of Manchester alone, 35 factories in the steel sector were seized over the course of seven weeks in March and April, involving up to 30,000 strikers. ${ }^{46}$ The successful actions of the workers of the Upper Clyde Shipbuilders in Glasgow, faced with the closure of the site, had probably provided the impetus for the massive use of occupations in Britain. The Conservative government of Edward Heath was forced to go back on its "lame duck" policy - the brainchild of Secretary of State for Trade and Industry John Davies - which meant the state would not provide financial assistance to companies not deemed to be viable. In late February 1972, the government announced a £35 million rescue plan to prevent the shipyards from closing down. ${ }^{47}$ This significant concession was interpreted by British activists as a victory, and would contribute to making workplace occupations the flagship tactic of the decade to fight against closures and redundancies, both in the private and public sectors.

\section{Student-worker committees}

The alliance between students and workers was one of the most acclaimed aspects of the French May. This coalition took concrete forms, owing to joint actions and the creation of a new type of organisational body to coordinate actions: student-worker committees. This tactical innovation emanated from the wariness felt by activists vis-àvis the leadership of the traditional organisations supposed to represent their interests, such as trade unions or established political parties. In a sidebar of the frontpage of the French student newspaper Action, activists explained that the goal of those committees was to organise mass struggle by enabling workers and students to effectively take part in discussions and actions, instead of relying on representatives ${ }^{48}$ Those committees mushroomed during the month of May, and by the $19^{\text {th }}, 148$ had been formed in Paris alone. ${ }^{49}$ In Britain, there were also many examples of collaboration between students and workers thanks to joint coordinating committees. One of the most successful examples occurred in the midst of the 1972 miners' strike. The National Union of Mineworkers (NUM) had launched a national strike in early January, and support was widespread in the mining community across the country. Mining activities came to a halt, and coal depots and power stations were picketed. In East Anglia, a delegation of Yorkshire miners had been sent to prevent American and Australian coal from being unloaded in the small ports of the area, and to picket power stations. To help them in their struggle, students from Essex University decided to occupy their university and use it as a base to coordinate action for the miners' strike. Action committees with equal representation of students and miners were created. They had daily meetings inside the university and decided on the practical organisation of the strike in the area. NUM flying pickets were billeted in the premises, and students provided significant help in reporting coal movement in the area, manning the pickets, printing and distributing leaflets, or even organising a benefit concert to raise money for the strike 
fund..$^{50}$ This instance of student-miner collaboration was not an isolated incident. During the course of the same industrial conflict, students from the universities of Canterbury, Norwich and Hull organised to help the miners, and so did the activists of the London School of Economics, who reinforced pickets at Battersea power station and provided material support to a Kent branch of the NUM, with whom they developed close personal bonds. A participant on the Battersea picket lines concluded his testimony by drawing a parallel with the French May, suggesting that the episode had become a textbook case of a successful alliance between students and workers: "As the French discovered in 1968, students and workers can support each other with great validity and effect." ${ }^{51}$ In 1974, during another miners' strike, the collaboration between the LSE students and the Kent miners was renewed, showing that the links created were more than just a fad.

\section{Barricades in Northern Ireland}

In the eyes of radical left activists, Northern Ireland was the place where a popular uprising against the forces of the state seemed most likely in the United Kingdom in 1969. At the time, a civil rights movement had emerged, campaigning to end religious discrimination against the Catholic minority. Its organisers had voluntarily chosen the model of the American civil rights movement to break away from the Republican and Loyalist protest traditions, stressing its non-sectarian and non-violent character. ${ }^{52}$ Within this movement, a radical organisation had been created at Queen's University, in Belfast, named the People's Democracy, whose membership was not restricted to students and cut across the communal divide. It had been formed in reaction to the violent repression of a civil rights demonstration by the Royal Ulster Constabulary, and bore the main characteristics of most New Left groups of that period, such as its strong focus on participatory democracy. ${ }^{53}$ Many of its members were also affiliated to radical left organisations such as the Young Socialists or the Revolutionary Socialist Student Federation, created to emulate the French May. ${ }^{54}$ This explains why these young activists resorted to the same tactic used by French students to fight against the police: building barricades.

On 4 January 1969 , the final day of the march organised by the People's Democracy from Belfast to Derry-Londonderry, the young protesters were ambushed by a group of Loyalists at Burntollet Bridge, and several of them were injured. When the marchers reached their destination, the news of the attack spread in the city, sparking scuffles between young Catholics and the police, who, due to obvious collusion with Loyalist attackers, were believed to have deliberately led the marchers into a trap. ${ }^{55} \mathrm{In}$ retaliation, a group of policemen raided the Bogside, a Catholic neighbourhood, stoning houses and assaulting residents. To protect the area from further police attacks, barricades were erected. But in this particular instance, the use of the tactic did not stem from the Republican tradition, but from the famous Night of the Barricades in Paris. Even the subsequent government investigation concluded from witness testimonies that the drive to build barricades had come from "some of the most politically extreme elements in the People's Democracy." ${ }^{56}$ Indeed, the nicknames that these young activists gave to this episode and to its participants smacked unmistakably of French influence. They called the experiment "the Derry Commune" and themselves "the Derry Communards", just like Parisian students who had also described their own actions as a re-enactment of the 1871 Paris Commune after the Night of the Barricades. ${ }^{57}$ In their 
descriptions of the atmosphere behind the barricades, the radical left participants presented the situation in strikingly utopian terms:

Behind the barricades the embryo of a new society developed - a society distinguished from the rest of the world by the camaraderie and interdependence that was necessary for the co-ordinated running of Free Derry. Such features were manifest in the willingness of each man to take his time on the barricades, by the co-operation of the people in feeding the people, by the communal cigarette packets, and by the setting up of a Free Derry Radio as an expression of the community's unity of action..$^{58}$

Like French protesters before them, Northern Irish activists created temporary alternative institutions, like a pirate radio or a militia to replace the police, who were barred from the neighbourhood. The "Derry Commune" was to last only six days. It would be the first episode of the Free Derry experiment. The barricades would come up again a few months later, both in Derry-Londonderry and in Belfast. But the atmosphere behind the barricades soon proved to be very different, as Republican speeches got more cheers than Socialist ones, ${ }^{59}$ and positions increasingly polarised along the historical sectarian divide, plunging Northern Ireland into armed conflict.

\section{Conclusion}

The French May captured the imagination of British activists. Because they could perceive a number of similarities between their situation and that of their French counterparts, the ideology, slogans and tactics of the French May diffused across the Channel, mainly owing to the alternative press and direct personal contacts between the two groups. Although diffusion processes were at work in the months following May 1968, their most significant impacts did not materialise in Britain until the early 1970s, when the wave of protest reached its peak. The collective action frames borrowed from the French activists helped to catalyse the student and worker movements, fostering instances of collaboration between both groups, while factory and university occupations became flagship tactics during the decade. In Northern Ireland, the adoption of these non-sectarian frames and tactics did not yield the desired result. Instead of uniting the Protestant and Catholic working classes against the elite, escalating protests triggered a backlash accompanied by the rise of sectarian violence.

Because diffusion is not a process of irrational mimicry but an operation which requires the active construction of meaning by adopters, the diffused items often take on a life of their own, once transplanted and adapted to their new contexts. Frenchstyle factory occupations soon evolved into a British innovation: the work-in, a type of occupation where production continues under workers' control in order to demonstrate to public opinion that the strikers are willing to work in order to save their jobs. Thanks to the success of the workers of the Upper Clyde Shipbuilders - who eventually managed to save their shipyards from the announced closure - the tactic was borrowed by other groups of workers, even spreading to the public sector, where hospital employees used it to fight against closures in the late 1970s. ${ }^{60}$ 


\section{BIBLIOGRAPHY}

\section{Press articles from the period studied}

Action, 7 May 1968, "Nous aussi, on étudie".

Action, 21 May 1968, "Les plans de l'ennemi”.

Action, 21 May 1968, "S'organiser".

Action, 21 May 1968, "Vôtre lutte est la nôtre".

Beaver, 12 November 1964, “L.S.E. Secession”.

Beaver, 14 October 1965, "LSE Left".

Beaver, 24 April 1969, "Examinations”.

Beaver, 17 February 1972, "On the picket-lines".

Black Dwarf, 1 June 1968, "Paris City of Hope".

Black Dwarf, 1 June 1968, “The Night of May 10".

Black Dwarf, 1 June 1968, “Theory Turned sideways”.

Black Dwarf, 1 June 1968, “We're students too!”.

Black Dwarf, 1 June 1968, "We will not be the watch-dogs of capital".

Black Dwarf, 5 July 1968, “RSSF: Revolutionary students or student revolutionaries?”.

Black Dwarf, 5 July 1968, “The New Vanguard”.

Black Dwarf, 15 October 1968, “Workers and Students Don't Demand Occupy your Schools your Factories".

Black Dwarf, 27 January 1969, “The Ulster Upsurge”.

Black Dwarf, 24 April 1969, "May Day Commitment".

Black Dwarf, 24 April 1969, “May Day Strike in LSE”.

Black Dwarf, 16 September 1969, “Worker-student unity - how real are the prospects?”.

Campus, 11 October 1968, "The role of the student in society".

Institute for Workers' Control Pamphlet, 17, "General Electric Company - English Electric".

Irish Democrat, March 1967, "United organisation for civil rights".

Nouvel Observateur, 15 May 1968, “Notre Commune du 10 mai”.

Peace News, 29 January 1960, “The New Left”.

Peace News, 17 January 1969, "Derry squat-in goes on".

Peace News, 17 January 1969, “The Civil Righters".

Peace News, 15 August 1969, “Ambush at Burntollet: 'Ulster police helped”.

Peace News, 29 August 1972, "Behind the Bogside Barricades". 
Redbrick, 11 February 1970, "The National Situation".

Red Mole, 7 February 1972, "Miners and students versus the State".

Red Mole, 13 March 1972, "Tory retreat UCS”.

Red Mole, "Miners' Strike Special", no. 2, 1972, "Essex shows the way".

Red Weekly, 27 November 1975, “The Manchester Engineers Occupations”.

Socialist Challenge, 3 November 1977, "Hounslow conference: How can we halt hospital closures".

Solidarity, June 1968, “Paris: May 1968”.

Union News, 17 March 1967, "LSE Delegation is to Negotiate".

Union News, 1 March 1968, “3-Day Sleep-in Victory”.

Union News, 21 June 1968, "In the year of student rebellion: How I see the future".

Union News, 21 June 1968, “'Majority' Stirs Now”.

Union News, 7 February 1969, “We are the nation's investment but are we being educated or exploited?".

Union News, 27 February 1970, "Oxford sits in".

Union News, 27 February 1970, “The Warwick affair - Is it just a personal issue?”.

Week, June 1968, "The politics of the student upsurge".

Workers' Fight, June 1968, “Meanwhile - In France and in Britain the struggle continues!”.

\section{Other sources}

Adam, Gérard, "Etude statistique des grèves de mai-juin 1968”, Revue française de science politique, XX:1, 1970.

Ali, Tariq, Street Fighting Years: an Autobiography of the Sixties, (London, Verso, 2005).

Benford, Robert and Snow, David, "Framing Processes and Social Movements: An Overview and Assessment", Annual Review of Sociology, 26, 2000.

Cameron Commission, Cameron Report: Disturbances in Northern Ireland, 1969, HSMO, <https:// cain.ulster.ac.uk/hmso/cameron.htm\#chap5> [29 April 2019].

Cliff, Tony, A World To Win: Life of a Revolutionary, (London, Bookmarks Publications, 2000).

Devlin-McAliskey, Bernadette, The Price of My Soul, (London, Pan Books, 1972).

Giblet, 19 October 1966, "Three views of Warwick Second Year”.

Hoefferle, Caroline, British Student Activism in the Long Sixties (New York, Routledge, 2013).

Kurlansky, Mark, 1968: The Year that Rocked the World (London, Jonathan Cape, 2004).

Leeds Students, 4 December 1970, “It's everybody out!”.

McAdam, Doug and Rucht, Dieter, "The Cross-National Diffusion of Movement Ideas", Annals of the American Academy of Political Science, DXXVIII:1, July 1993.

Marwick, Arthur The Sixties: cultural revolution in Britain, France, Italy, and the United States, 1958-1974 (Oxford, Oxford University Press, 1998). 
Times Higher Education, "Participation rate: now we are 50", 25 July 2013, <https:// www.timeshighereducation.com/features/participation-rates-now-we-are-50/2005873.article> consulted on 13 January 2020.

Révauger, Jean-Paul, Le Pouvoir Aboli : L'idée d'autogestion en Grande-Bretagne 1900-1983 (Doctoral dissertation, Grenoble III, 1986).

Sandbrook, Dominic, White Heat: A History of Britain in the Swinging Sixties (London, Abacus, 2007).

Wrigley, Chris, British Trade Unions since 1933 (Cambridge, Cambridge University Press, 2002).

\section{NOTES}

1. “Theory Turned sideways", Black Dwarf, 1 June 1968, pp. 4-5.

2. "Paris City of Hope", Black Dwarf, 1 June 1968, pp. 4-5.

3. Arthur Marwick, The Sixties: cultural revolution in Britain, France, Italy, and the United States, 1958-1974 (Oxford, Oxford University Press, 1998), p. 584.

4. Dominic Sandbrook, White Heat: A History of Britain in the Swinging Sixties (London, Abacus, 2007), p. 543.

5. Doug McAdam and Dieter Rucht, "The Cross-National Diffusion of Movement Ideas", Annals of the American Academy of Political Science, DXXVIII:1, July 1993, p. 59.

6. Doug McAdam and Dieter Rucht, "The Cross-National Diffusion of Movement Ideas", Annals of the American Academy of Political Science, DXXVIII:1, July 1993, pp. 63-64.

7. Mark Kurlansky, 1968: The Year that Rocked the World (London, Jonathan Cape, 2004), p. 217.

8. "L.S.E. Secession", The Beaver, 12 November 1964, p. 2.

9. "Three views of Warwick Second Year", Giblet, 19 October 1966, p. 3.

10. “The New Left”, Peace News, 29 January 1960, p. 2.

11. Chris Wrigley, British Trade Unions since 1933 (Cambridge, Cambridge University Press, 2002), p. 41.

12. Gérard Adam, "Etude statistique des grèves de mai-juin 1968", Revue française de science politique, XX:1, p. 105.

13. "We will not be the watch-dogs of capital", Black Dwarf, 1 June 1968, p. 3.

14. "Nous aussi, on étudie", Action, 7 May 1968, p. 4.

15. "We're students too!", Black Dwarf, 1 June 1968, p. 3.

16. “Meanwhile - In France and in Britain the struggle continues!”, Workers' Fight, June 1968, p. 3.

17. “The Night of May 10", Black Dwarf, 1 June 1968, p. 3. "Paris: May 1968”, Solidarity, June 1968, pp. 1-49.

18. “RSSF: Revolutionary students or student revolutionaries?", Black Dwarf, 5 July 1968, p. 3.

19. Robert D. Benford and David A. Snow, "Framing Processes and Social Movements: An Overview and Assessment", Annual Review of Sociology, 26, 2000, p. 615.

20. Ibid. p. 616.

21. "The role of the student in society", Campus, 11 October 1968, p. 7.

22. Tony Cliff, A World to Win: Life of a Revolutionary, (London, Bookmarks Publications, 2000), p. 59.

23. "In the year of student rebellion: How I see the future", Union News, 21 June 1968, p. 6.

24. "We are the nation's investment but are we being educated or exploited?", Union News, 7 February 1969, p. 17.

25. “Les plans de l'ennemi”, Action, 21 May 1968, pp. 1-2.

26. “The New Vanguard”, Black Dwarf, 5 July 1968, p. 2.

27. "May Day Commitment", Black Dwarf, 24 April 1969, p. 8.

28. “May Day Strike in LSE”, Black Dwarf, 24 April 1969, p. 6. 
29. Robert D. Benford and David A. Snow, "Framing Processes and Social Movements: An Overview and Assessment", Annual Review of Sociology, 26, 2000, p. 624.

30. "Participation rate: now we are 50", Times Higher Education, 25 July 2013, https:// www.timeshighereducation.com/features/participation-rates-now-we-are-50/2005873.article consulted on 13 January 2020.

31. "Vôtre lutte est la nôtre", Action, 21 May 1968, p. 5. "Examinations", The Beaver, 24 April 1969, p. 6.

32. “Worker-student unity - how real are the prospects?", Black Dwarf, 16 September 1969, p. 5. “It's everybody out!", Leeds Students, 4 December 1970, p. 1.

33. "Paris: May 1968", Solidarity, June 1968, p. 40. "May Day Strike in LSE”, Black Dwarf, 24 April 1969 , p. 6.

34. "The politics of the student upsurge", The Week, June 1968, p 7.

35. Robert D. Benford and David A. Snow, "Framing Processes and Social Movements: An Overview and Assessment", Annual Review of Sociology, 26, 2000, p. 615.

36. "Paris: May 1968”, Solidarity, June 1968, p. 32.

37. "Vôtre lutte est la nôtre", Action, 21 May 1968, p. 5.

38. "Workers and Students Don't Demand Occupy your Schools your Factories", Black Dwarf, 15 October 1968, p. 1.

39. "LSE Delegation is to Negotiate", Union News, 17 March 1967, p. 1.

40. “3-Day Sleep-in Victory”, Union News, 1 March 1968, p. 1.

41. Caroline Hoefferle, British Student Activism in the Long Sixties (New York, Routledge, 2013) p. 123.

42. “'Majority' Stirs Now”, Union News, 21 June 1968, p. 1.

43. "The National Situation", Redbrick, 11 February 1970, p. 1. "Oxford sits in", Union News, 27 February 1970, p. 1. “The Warwick affair - Is it just a personal issue?”, Union News, 27 February 1970, pp. 6-7.

44. “General Electric Company - English Electric”, Institute for Workers' Control Pamphlet, 17, p. 13.

45. Ibid. p. 10.

46. “The Manchester Engineers Occupations”, Red Weekly, 27 November 1975, p. 6.

47. "Tory retreat UCS", The Red Mole, 13 March 1972, p. 3.

48. "S'organiser", Action, 21 May 1968, p. 1.

49. Ibid.

50. "Miners and students versus the State", The Red Mole, 7 February 1972, p. 12. "Essex shows the way", The Red Mole, "Miners' Strike Special", no. 2, 1972, p. 3.

51. "Miners and students versus the State", The Red Mole, 7 February 1972, p. 12. "On the picketlines", The Beaver, 17 February 1972, p. 5.

52. "United organisation for civil rights", The Irish Democrat, March 1967, p. 8.

53. “The Civil Righters", Peace News, 17 January 1969, pp. 4-7.

54. Cameron Commission, Cameron Report: Disturbances in Northern Ireland, 1969, HSMO, §58, <https://cain.ulster.ac.uk/hmso/cameron.htm\#chap5> [29 April 2019].

55. "Ambush at Burntollet: 'Ulster police helped”, Peace News, 15 August 1969, p. 1. Bernadette Devlin-McAliskey, The Price of My Soul, (London, Pan Books, 1972) pp. 140-42.

56. Cameron Commission, Cameron Report: Disturbances in Northern Ireland, 1969, HSMO, §176, <https://cain.ulster.ac.uk/hmso/cameron.htm\#chap5> [29 April 2019].

57. "Notre Commune du 10 mai", Le Nouvel Observateur, 15 May 1968, p. 32. "The Civil Righters", Peace News, 17 January 1969, pp. 4-7. “The Ulster Upsurge”, Black Dwarf, 27 January 1969, p. 12.

58. "Derry squat-in goes on", Peace News, 17 January 1969, p. 2.

59. "Behind the Bogside Barricades", Peace News, 29 August 1972, p. 12.

60. "Hounslow conference: How can we halt hospital closures", Socialist Challenge, 3 November 1977, p. 3. 


\section{ABSTRACTS}

The well-known events of May 1968 in France struck a chord with British radical left activists. This paper examines the impact of the French May on British protest thanks to the analysis of diffusion processes between France and the United Kingdom. Because they perceived similarities between the two contexts, British protesters could identify with their French counterparts, thus providing the necessary condition for diffusion processes to occur. Information was then transferred through the mass media and the alternative press, as well as through personal contacts between both groups. British activists adopted the collective action frames and some of the tactics of the French May. Frustrated by their lack of participation in the running of their universities and workplaces, British students and workers chose to occupy their institutions, to create alternative organisational structures where they would be involved in the decisionmaking process. Finally, in spite of its particular historical context, Northern Ireland was also influenced by the French May, eclipsing for a brief moment, the local revolutionary Republican tradition.

Les célèbres évènements de mai 1968 en France trouvèrent de l'écho auprès des militants de la gauche radicale britannique. Cet article examine l'impact du mai 1968 français sur la contestation au Royaume-Uni grâce à l'analyse des processus de diffusion à l'œuvre entre les deux pays. Du fait des ressemblances perçues entre les deux contextes, les militants britanniques purent s'identifier à leurs équivalents français, remplissant ainsi la condition nécessaire pour que les processus de diffusion aient lieu. L'information a ensuite été transférée par le biais des médias de masse et de la presse alternative, ainsi que grâce à des contacts personnels entre les deux groupes. Les militants britanniques adoptèrent les cadres d'action collective et certaines tactiques de mai 1968. Frustrés par leur manque d'implication dans la gestion de leurs universités et de leurs lieux de travails, les étudiants et les ouvriers britanniques choisirent d'occuper leurs institutions, de créer des structures organisationnelles alternatives leur permettant de participer au processus décisionnel. Enfin, en dépit de son contexte historique particulier, l'Irlande du Nord fut également influencée par le mai français, éclipsant un bref instant la tradition révolutionnaire républicaine locale.

\section{INDEX}

Mots-clés: mai 1968, diffusion, cadres d'action collective, occupations d'universités, occupations d'usines, barricades

Keywords: French May, diffusion, collective action frames, university occupations, factory occupations, barricades

\section{AUTHOR}

\section{CLAIRE MANSOUR}

CAS (EA 801), Université Toulouse Jean Jaurès

Claire Mansour, Ph.D., is a lecturer at the University of Toulouse 2-Jean Jaurès and a member of the research team CAS (EA 801). Her research focuses on the diffusion of social movements in the 
United Kingdom, mainly in the 1960s and 1970s. Her doctoral dissertation was entitled "Diffusion and evolution of social movements during the Long Sixties in the United Kingdom: 1956-1979". 